\title{
LOCUS OF CONTROL PEMODERASI PENGARUH KECERDASAN INTELEKTUAL, EMOSIONAL, DAN SPIRITUAL PADA KEPUTUSAN ETIS KONSULTAN PAJAK
}

\author{
I Made Indra Pratama ${ }^{1}$ \\ Dewa Gede Wirama ${ }^{2}$
}

${ }^{1}$ Fakultas Ekonomi dan Bisnis Universitas Udayana, Bali, Indonesia

${ }^{1}$ Email: indrapaper@gmail.com

${ }^{2}$ Fakultas Ekonomi dan Bisnis Universitas Udayana, Bali, Indonesia

\begin{abstract}
ABSTRAK
Penelitian ini bertujuan untuk menguji pengaruh kecerdasan intelektual, emosional, dan spiritual pada keputusan etis konsultan pajak dengan locus of control sebagai variabel pemoderasi.Populasi penelitian adalah seluruh konsultan pajak yang bekerja pada kantor konsultan pajak di daerah Bali. Sampel penelitian ditentukan dengan menggunakan metode purposivesampling, kriteria yang digunakan ialah konsultan pajak yang memiliki minimal satu sertifikat brevet. Teknik analisis data yang digunakan dalam penelitian adalah analisis regresi linier berganda dan moderates regression analysis. Hasil pengujian membuktikan bahwa variabel kecerdasan intelektual berpengaruh pada keputusan etis,kecerdasan emosional berpengaruh pada keputusan etis,kecerdasan spiritual berpengaruh pada keputusan etis. Locus of control memoderasi pengaruh kecerdasan intelektual, kecerdasan emosional, dan kecerdasan spiritual pada keputusan etis.
\end{abstract}

Kata kunci: kecerdasan intelektual, emosional, spiritual, locus of control

\begin{abstract}
This study aims to examine the influence of intellectual, emotional, and spiritual intelligence on ethical decisions of tax consultants with locus of control as a moderating variable. The research population is all tax consultants who work at tax consultancy office in Bali area. The sample of research is determined by using purposive sampling method, the criterion used is a tax consultant who has at least one certificate brevet. Data analysis technique used in this research is multiple linear regression analysis and moderates regression analysis. The test results prove that intellectual intelligence variables affect the ethical decisions,emotional intelligence affects ethical decisions, spiritual intelligence influences ethical decisions. Locus of controlmoderate the influence intellectual intelligence, emotional intelligence, and spiritual intelligence on ethical decisions.
\end{abstract}

Keywords: Intellectual intelegence, emotional, spiritual, locus of control 
I Made Indra Pratama, dan Dewa Gede Wirama. Pengaruh Kecerdasan Intelektual.....

\section{PENDAHULUAN}

Pajak merupakan iuran dari rakyat kepada negara berdasarkan UndangUndang, sehingga hal ini dapat dipaksakan, dan tidak mendapati balas jasa secara langsung (Devos, 2012). Penerimaan pajak di Indonesia pada tahun 2016 mencapai Rp 870,954 triliun (www.pajak.go.id), hal ini tentunya dikarenakan oleh iuran yang dilakukan masyarakat atau disebut dengan wajib pajak. Dalam melakukan kewajiban perpajakannya, wajib pajak menggunakan saran yang diberikan oleh konsultan pajak dikarenakan ketidaktahuan wajib pajak akan peraturan perpajakan yang berlaku, hal ini membuat profesi konsultan pajak menjadi penting. Konsultan pajak secara umum merupakan profesi yang memberikan jasa konsultasi kepada orang pribadi atau perusahaan dalam hal pemenuhan kewajiban perpajakan.

Profesi dibidang konsultan pajak tersebut merupakan profesi yang penuh dengan masalah dalam hal keputusan etis, karena sering dihadapkan pada kondisi dilema etis yang senantiasa mengancam profesionalitas profesinya. Terdapat kasus yang terjadi dalam profesi konsultan pajak tersebut, yakni kasus Gayus Tambunan yang melibatkan konsultan pajak Robertus Santonius dan Hendro Tirtawijaya yang membantu kliennya untuk melakukan kecurangan. Dilema etis yang dihadapi konsultan pajak membuatnya untuk melakukan keputusan yang tidak etis, karena imbalan ekonomis yang cukup material.

Budileksmana (2000) dan Achmad (2014) menyatakan konsultan pajak memiliki fungsi tax consulting, tax settlement, tax mediation, attorney at tax law, dan agent of tax awareness. Hughes dan Moizer (2015) membagi jasa yang 
disediakan oleh konsultan pajak menjadi dua jenis yaitu kepatuhan pajak dan perencanaan pajak/penghindaran pajak.Perencanaan pajak terjadi ketika konsultan pajak berupaya untuk menemukan cara-cara untuk mengurangi kewajiban wajib pajak.

Konsultan pajak memiliki kode etik untuk menjaga independensi, profesionalisme, dan integritasnya dalam menjalankan profesinya. Disisi lain, studi Tan (1999) menunjukkan bahwa ada kecenderungan bagi klien yang tidak setuju dengan rekomendasi konsultan pajaknya dan memilih untuk mengakhiri penggunaan jasanya, meskipun tidak ada bukti yang jelas untuk menunjukkan bahwa ini hanya terjadi ketika keinginan mereka untuk rekomendasi konservatif tidak terpenuhi. Seorang konsultan pajak yang menjalankan profesinya sesuai dengan kode etik dapat dipengaruhi oleh tiga faktor yaitu faktor individu, faktor organisasi, dan faktor psikologis. Beberapa faktor individu yang berasal dari dalam diri seseorang adalah kecerdasan intelektual, kecerdasan emosional, serta kecerdasan spiritual. Menurut Amellia (2012) kecerdasan intelektual atau intelegensi merupakan kemampuan mental individu yang dapat dipergunakan untuk menyesuaikan diri di dalam lingkungan yang baru, serta dapat memecahkan masalah yang dihadapi dengan cepat dan tepat. Menurut Goleman (2005) semakin kompleks pekerjaan, semakin penting kecerdasan emosi. Emosi yang lepas kendali dapat membuat orang pandai menjadi bodoh. Tanpa kecerdasan emosi, seseorang tidak akan mampu menggunakan kemampuan kognitif mereka sesuai dengan potensi yang maksimum. Demikian halnya sebagai seorang konsultan pajak, kecerdasan emosional diperlukan untuk membantu seorang konsultan pajak 
I Made Indra Pratama, dan Dewa Gede Wirama. Pengaruh Kecerdasan Intelektual.....

dalam melakukan konsultasi maupun pemeriksaan guna mendeteksi kebenaran atas laporan perpajakan yang dilakukan klien.

Kecerdasan spiritual adalah kecerdasan untuk menghadapi dan memecahkan persoalan makna dan nilai yang menempatkan perilaku dan hidup manusia dalam konteks yang lebih luas yang memungkinkan seseorang untuk menyatukan hal-hal yang bersifat intrapersonal dan interpersonal, serta menjembatani kesenjangan antara diri sendiri dan orang lain (Agustini, 2013). Seorang konsultan pajak yang memiliki pemahaman atau kecerdasan emosi dan kecerdasan spiritual yang tinggi, akan mampu bertindak atau berperilaku dengan etis dalam profesinya dan organisasi. Apabila seorang konsultan pajak tidak memiliki kemampuan spiritual yang tinggi, maka seorang konsultan pajak tersebut bisa saja melakukan hal yang menyimpang misalnya saja tidak jujur. Dalam profesi konsultan pajak, seorang konsultan pajak dituntut integritas, dan kejujuran agar obyektif. Seorang konsultan bisa saja tidak jujur karena mendapat imbalan lebih dari klien. Oleh karena itu kecerdasan spiritual merupakan landasan yang diperlukan untuk memfungsikan kecerdasan intelektual dan kecerdasan emosional secara efektif. Secara singkat kecerdasan spiritual mampu mengintegrasikan dua kemampuan lain yang sebelumnya telah disebutkan yaitu kecerdasan intelektual dan kecerdasan emosional (Idrus 2002).

Trevino (1986) menyatakan bahwa pembuatan keputusan etis seseorang akan sangat tergantung pada faktor-faktor individual dari orang yang membuat keputusan. Sehingga diperlukan penelitian yang lebih lanjut untuk mengkaji faktor-faktor yang dapat mempengaruhi pembuatan keputusan etis konsultan 
pajak, terutama faktor-faktor yang bersifat internal individu. Salah satu hal yang dapat membantu seseorang dalam menghadapi dilema etika adalah locus of control. Greenhaus (2006) mendefinisikan locus of control mengacu pada kecenderungan menempatkan persepsi atas suatu kejadian atau hasil yang didapat dalam hidup individu apakah sebagai hasil dari dirinya sendiri atau karena bantuan dari sumber-sumber di luar dirinya dimana ia sendiri memiliki peran yang sangat sedikit, seperti keberuntungan, takdir, atau bantuan orang lain. Sedangkan menurut Rotter (1996) locus of control adalah suatu variabel kepribadian, yang didefinisikan sebagai keyakinan individu terhadap mampu tidaknya mengontrol nasib. Menurut Rotter (1996) terdapat dua konstruk locus of control, yaitu locus of control internal dan locus of control eksternal. Seseorang dengan locus of control internal percaya bahwa mereka memiliki pengendalian atas takdir mereka. Sedangkan locus of control eksternal mengacu kepada keyakinan bahwa, keberuntungan, nasib, orang yang lebih berkuasa, dan hal-hal diluar kendali dirinya dapat lebih kuat untuk membuat keputusan tentang kehidupan dan hasil dari seorang individu. Trevino (1986) berpendapat bahwa seseorang dengan locus of control eksternal mungkin kurang bertanggungjawab atas konsekuensi perilaku etis atau tidak etisnya dan lebih berhubungan dengan kekuatan dari luar. Sedangkan seseorang dengan locus of control internal lebih bertanggung jawab atas konsekuensi perilakunya dan pedoman perilaku baik dan buruknya ditentukan dari dalam diri mereka sendiri. Jones dan Kavanagh (1996) juga berpendapat bahwa seseorang dengan locus of control eksternal dirasakan kurang bertanggungjawab dengan hasil dari tindakannya dibandingkan seseorang dengan 
I Made Indra Pratama, dan Dewa Gede Wirama. Pengaruh Kecerdasan Intelektual.....

locus of control internal. Seseorang dengan locus of control internal yang tinggi lebih mengenali secara langsung hubungan antara perilaku dan hasil dari tindakannya. Akibatnya, seseorang dengan locus of control internal lebih bertanggung jawab dengan hasil dari tindakan atau perilakunya terhadap diri mereka sendiri dan menentukan sendiri mengenai apa yang benar dan salah untuk pedoman perilaku. Oleh karena itu, seseorang dengan locus of control internal cenderung memilih untuk terlibat dalam perilaku etis dan tidak terlibat dalam perilaku tidak etis. Sebaliknya, seseorang dengan locus of control eksternal lebih bertanggung jawab dengan pihak-pihak lain dan faktor-faktor situasional, oleh karena itu mereka cenderung terlibat dalam perilaku tidak etis.

Beberapa penelitian yang berhubungan dengan penelitian etika telah banyak dilakukan. Shaub dkk. (1993) menemukan bahwa orientasi etika mempengaruhi keputusan etis, komitmen profesi, dan organisasi. Penelitian Fallah (2006) menunjukkan bahwa budaya etis organisasi berpengaruh pada idealisme dan tidak berpengaruh pada relativisme, sedangkan relativisme berpengaruh signifikan pada sensitivitas etika dan idealisme tidak berpengaruh terhadap sensitivitas etika. Gusti dan Syahril (2007) menemukan bahwa skeptisme profesional dan situasi audit berpengaruh signifikan terhadap ketepatan pemberian opini audit, sedangkan etika, pengalaman, dan keahlian audit tidak berpengaruh signifikan terhadap ketepatan pemberian opini audit. Hasil penelitian Aziza dan Salim (2007) menunjukkan bahwa orientasi etika berpengaruh signifikan terhadap komitmen dan sensitivitas etika, sedangkan komitmen profesional dan organisasional tidak berpengaruh terhadap sensitivitas etika. 
Abdurrahman dan Yuliani (2011) meneliti tentang determinasi pembuatan keputusan etis auditor internal, hasil penelitiannya menunjukkan bahwa orientasi etika (yang diukur dengan indikator idealisme), komitmen profesional, dan independensi berpengaruh signifikan terhadap pembuatan keputusan etis, sedangkan pengalaman auditor tidak berpengaruh terhadap pembuatan keputusan etis. Uyar dan Ozer (2011) menemukan bahwa orientasi etika berpengaruh signifikan pada pembuatan keputusan etis dan komitmen profesional, serta penelitian yang dilakukan oleh Ashari (2013) menemukan bahwa persepsi tentang korupsi berpengaruh terhadap perilaku antikorupsi, dukungan antikorupsi berpengaruh terhadap penilaian risiko, sensitivitas etika berpengaruh terhadap persepsi tentang korupsi, skeptisme profesional tidak berpengaruh terhadap sensitivitas etika, dan skeptisme profesional berpengaruh terhadap penilaian risiko. Suardika (2015) menemukan bahwa idealisme, komitmen profesional, dan skeptisme profesional berpengaruh pada keputusan etis konsultan pajak di Provinsi Bali. Tikollah dkk. (2006), menemukan bahwa kecerdasan intelektual, kecerdasan emosional dan kecerdasan intelektual berpengaruh pada sikap etis. Lisda Afrida (2009), menemukan bahwa kecerdasan emosional dan kecerdasan spiritual berpengaruh terhadap perilaku etis auditor serta dampaknya pada kinerja. Namun penelitian Atmaja (2014) yang tidak menemukan pengaruh kecerdasan emosi dan kecerdasan spiritual pada perilaku etis profesi akuntan.

Karena terdapatnya perbedaan hasil penelitian terdahulu, maka peneliti mencoba menambahkan penelitian ini dengan variabel moderasi locus of control yang peneliti duga dapat memperkuat ataupun memperlemah hubungan antara 
I Made Indra Pratama, dan Dewa Gede Wirama. Pengaruh Kecerdasan Intelektual.....

variabel-variabel kecerdasan intelektual, kecerdasan emosional dan kecerdasan spiritual pada variabel keputusan etis. Maka dari itu peneliti tertarik untuk melakukan penelitan lebih lanjut mengenai konsultan pajak dengan judul pengaruh kecerdasan intelektual, kecerdasan emosional, dan kecerdasan spiritual pada keputusan etis konsultan pajak di Daerah Bali dengan locus of control sebagai variabel moderasi.

Grand theory penelitian ini adalah theory of planned behavior.Fishbein dan Ajzen pada awal tahun 1970 mendefinisikan theory of planned behaviour yakni teori yang menjelaskan bagaimana keinginan perilaku yang memotivasi individu untuk terlibat dalam perilaku yang didefinisikan oleh sikap yang mempengaruhi perilaku dengan asumsi utama adalah individu rasional dalam mempertimbangkan tindakan mereka dan implikasi dari tindakan mereka. Atmaja (2014) menjelaskan bahwa sikap adalah pernyataan evaluatif, baik yang menguntungkan atau tidak menguntungkan tentang obyek, orang, atau peristiwa sehingga sikap bukanlah perilaku, tetapi sikap menghadirkan suatu kesiapsiagaan untuk tindakan yang mengarah pada perilaku jadi dapat dikatakan bahwa sikap merupakan wahana dalam membimbing perilaku.

Jika seseorang memiliki kecerdasan intelektual yang baik, maka mereka akan mampu memahami dan menjalankan tugasnya dengan sangat baik dan implikasinya kinerja mereka akan baik. Tugas yang dihadapi oleh seorang konsultan pajak merupakan suatu tugas yang menuntut konsultan pajak untuk memiliki pengetahuan, analisis, serta proses berpikir rasional yang digunakan untuk menarik sebuah keputusan bagi kliennya. Dengan kecerdasan intelektual 
yang tinggi yang dimiliki seorang konsultan pajak maka seorang konsultan pajak dapat memberikan keputusan yang etis kepada kliennya.

Hasil penelitian Tikollah (2006) dan Lisda (2009) menunjukkan bahwa kecerdasan intelektual berpengaruh positif terhadap keputusan etis. Dari uraian diatas maka dapat ditarik suatu hipotesis:

$\mathrm{H}_{1}$ : Kecerdasan intelektual berpengaruh pada keputusan etis konsultan pajak di Daerah Bali.

Secara khusus konsultan pajak membutuhkan kecerdasan emosional yang tinggi karena dalam lingkungan kerjanya konsultan pajak akan berinteraksi dengan banyak orang baik di dalam maupun di luar lingkungan kerja. Kecerdasan emosional berperan penting dalam membentuk moral disiplin seorang konsultan pajak. Dalam dunia kerja konsultan pajak, berbagai masalah dan tantangan yang harus dihadapi seperti tuntutan tugas dan masalah hubungan dengan orang lain baik dengan klien maupun lainnya. Masalah-masalah tersebut bukanlah suatu hal yang hanya membutuhkan kemampuan intelektualnya, tetapi dalam menyelesaikan masalah tersebut kemampuan emosi atau kecerdasan emosi lebih banyak diperlukan. Bila seorang konsultan pajak memiliki kecerdasan emosional yang tinggi maka keputusan dalam menghadapi masalahnya akan lebih baik.

Hasil penelitian Tikollah (2006) dan Lisda (2009) menunjukkan bahwa kecerdasan emosional berpengaruh positif terhadap keputusan etis. Dari uraian diatas maka dapat ditarik suatu hipotesis:

$\mathrm{H}_{2}$ : Kecerdasan emosional berpengaruh pada keputusan etis konsultan pajak di Daerah Bali. 
I Made Indra Pratama, dan Dewa Gede Wirama. Pengaruh Kecerdasan Intelektual.....

Suadnyana (2015) menyatakan bahwa peran kecerdasan spiritual adalah sebagai landasan yang diperlukan untuk memfungsikan kecerdasan intelektual dan kecerdasan emosional secara efektif.Sehingga orang dengan kecerdasan spiritual tinggi adalah orang yang memiliki prinsip dan visi yang kuat, mampu memaknai setiap sisi keidupan serta mampu mengelola dan bertahan dalam kesulitan dan kesakitan. Dengan kata lain orang dengan kecerdasan spiritual tinggi dapat menghasilkan keputusan yang etis dalam menghadapi suatu masalah.

Hasil penelitian Tikollah (2006) dan Lisda (2009) menunjukkan bahwa kecerdasan spiritual berpengaruh positif terhadap keputusan etis. Dari uraian diatas maka dapat ditarik suatu hipotesis:

$\mathrm{H}_{3}$ : Kecerdasan spiritual berpengaruh pada keputusan etis konsultan pajak di Daerah Bali.

Namun memiliki kecerdasan intelektual yang tinggi saja belum cukup jika orang tersebut tidak dapat mengendalikannya. Kemampuan untuk mengendalikan hal tersebut disebut dengan locus of control. Rotter (1996) mendefinisikan locus of control adalah cara pandang seseorang terhadap suatu peristiwa apakah dia dapat atau tidak dapat mengendalikan (control) peristiwa yang terjadi padanya. Locus of control dibagi menjadi dua yakni locus of control internal dan locus of control eksternal.

Locus of controlinternal adalah cara pandang bahwa segala hasil yang didapat, baik atau buruk adalah karena tindakan, kapasitas, dan faktor-faktor dari dalam diri mereka sendiri. Locus of control eksternal adalah cara pandang dimana 
segala hasil yang didapat, baik atau buruk berada di luar kontrol diri mereka tetapi karena faktor luar seperti keberuntungan, kesempatan, dan takdir.

Hal ini sesuai dengan hasil penelitian Mahadewi (2015) yakni locus of control dapat memoderasi Intelegence Quotient (IQ), dan Emotional Spiritual Quotients (ESQ) terhadap perilaku etis profesi akuntan publik.

$\mathrm{H}_{4}$ : Locus of control memoderasi pengaruh kecerdasan intelektual pada keputusan etis konsultan pajak di Daerah Bali.

Kecerdasan emosional berperan penting dalam membentuk moral disiplin seorang konsultan pajak. Dalam dunia kerja konsultan pajak, berbagai masalah dan tantangan yang harus dihadapi seperti tuntutan tugas dan masalah berhubungan dengan orang lain baik dengan klien maupun lainnya. Untuk dapat mengontrol kecerdasan emosional tersebut diperlukanlah locus of control. Karena locus of control dapat meningkatkan keyakinan seseorang konsultan pajak terhadap kecerdasan emosional yang dimilikinya sehingga hal ini dapat memperkuat keputusan yang akan diambilnya.

Menurut penelitian Mahadewi (2015) yakni locus of control dapat memoderasi Intelegence Quotient (IQ), dan Emotional Spiritual Quotients (ESQ) terhadap perilaku etis profesi akuntan publik.

$\mathrm{H}_{5}$ : Locus of control memoderasi pengaruh kecerdasan emosional pada keputusan etis konsultan pajak di Daerah Bali.

$$
\text { Zohar dan Marshall (2002) menyatakan bahwa }
$$

kecerdasan spiritual adalah kecerdasan untuk menghadapi dan memecahkan persoalan makna dan nilai, yaitu menempatkan perilaku dan hidup manusia dalam 
I Made Indra Pratama, dan Dewa Gede Wirama. Pengaruh Kecerdasan Intelektual.....

konteks makna yang lebih luas dan kaya, serta menilai bahwa tindakan atau hidup seseorang lebih bermakna dibandingkan dengan yang lain, sehingga memungkinkan seseorang untuk menyatukan hal-hal yang bersifat intrapersonal dan interpersonal, serta menjembatani kesenjangan antara diri dan orang lain. Hal ini berarti orang yang memiliki kecerdasan spiritual akan mewujudkanya dalam perilaku yang luhur (etis) dan menjadi salah satu faktor yang mempengaruhi sikap dan keputusan etis seseorang.

Locus of control dapat membantu seseorang untuk mengontrol kecerdasan spiritualnya. Sehingga keputusan yang dihasilkan oleh seorang konsultan pajak dapat lebih etis. Hal ini sesuai penelitian Mahadewi (2015) yakni locus of control dapat memoderasi Intelegence Quotient (IQ), dan Emotional Spiritual Quotients (ESQ) terhadap perilaku etis profesi akuntan publik.

$\mathrm{H}_{6}$ : Locus of control memoderasi pengaruh kecerdasan spiritual pada keputusan etis konsultan pajak di Daerah Bali.

\section{METODE PENELITIAN}

Penelitian ini dilakukan pada tahun 2017 di kantor konsultan pajak di Daerah Bali sebagai representasi dari kantor konsultan pajak di Indonesia, dikarenakan keterbatasan waktu dan biaya untuk melakukan penelitian. Seluruh kantor konsultan pajak di Daerah Bali berlokasi di Kota Denpasar dan Kabupaten Badung. Adapun daftar kantor konsultan pajak di Daerah Bali disajikan pada Tabel 1. 
Tabel 1

Daftar Konsultan Pajak di Daerah Bali

\begin{tabular}{cll}
\hline No. & \multicolumn{1}{c}{ Nama Kantor Konsultan Pajak } & \multicolumn{1}{c}{ Alamat } \\
\hline 1 & I Kadek Sumadi & Kompleks Pertokoan Genteng Biru-Dps \\
2 & I Kadek Agus Ardika, SE, Ak & JL. Tukad Pancoran - Denpasar \\
3 & Arief Satriawan, SE, Ak & JL. Teuku Umar-Denpasar \\
4 & Ketut A. Adi Krisna & Komp. Pertokoan Sudirman Agung-Dps \\
5 & Riza Edwindra, SE & JL. Gunung Merapi-Denpasar \\
6 & I Wayan Sentana Gotama, SE & JL. Gunung Agung-Denpasar \\
7 & Ketut Tarik, SE, SH, MM, Ak. & JL. Cok Agung Tresna-Denpasar \\
8 & Ni Made Galih Masari, SE, Ak & JL Diponogoro-Denpasar \\
9 & Drs. I Ketut Sipta Artha & JL. Tonja-Denpasar \\
10 & Maurin Dewiati Harianto & JL. Raya Kuta-Badung \\
11 & I Gde Santana & JL. Trijata-Denpasar \\
12 & I Gede Bujangga Hartawan, SE & JL. Danau Tamblingan Sanur-Denpasar \\
13 & I Gusti Ngr Bagus Juliarta, SE, Ak & JL. Danau Tondano Sanur-Denpasar \\
14 & I Gusti Nyoman Suastawa & JL. Raya Mambal-Badung \\
15 & I Made Amaya, SE, Ak & JL. Cargo Permai-Denpasar \\
16 & I Komang Yastana, SE & JL. Gunung Tambora-Denpasar \\
17 & N. Fian Varian Jaya S. & JL. Letda Tantular Denpasar \\
\hline Sumber: Direktori IKPI (2017) &
\end{tabular}

Jenis data yang digunakan dalam penelitian ini adalah data primer yang dikumpulkan melalui kuesioner dalam bentuk instrumen penelitian berupa pernyataan dan kasus. Populasi dalam penelitian ini adalah seluruh konsultan pajak yang bekerja pada kantor konsultan pajak di Daerah Bali yakni berjumlah 156 orang konsultan pajak. Sampel penelitian dipilih melalui purposive sampling yang menghasilkan 120 orang konsultan pajak sebagai responden. Kriteria pemilihan sampel terdiri dari: 1) Tidak dibatasi jabatannya, baik sebagai managing partner, manajer, konsultan senior, maupun konsultan junior. 2) Sekurang-kurangnya memiliki satu sertifikasi brevet.

Variabel penelitian terdiri dari variabel dependen, variabel independen dan variabel moderasi. Variabel dependen yaitu keputusan etis diukur menggunakan skenario kasus yang diadopsi dari penelitian Abdurahman (2011), variabel independen terdiri dari kecerdasan intelektual, kecerdasan emosional, dan kecerdasan spiritual, variabel independen diukur menggunakan kuesioner yang 
I Made Indra Pratama, dan Dewa Gede Wirama. Pengaruh Kecerdasan Intelektual.....

diapdosi dari penelitian Robin dan Judge (2008) dengan menggunakan skala Likert. Variabel moderasi yaitu locus of control diukur menggunakan skala locus of control yang dikembangkan oleh Rotter (1966).

Teknik analis data yang digunakan adalah regresi linier berganda dan moderated regression analysis. Analisis regreisi linier berganda digunakan untuk mengetahui pengaruh langsung antara variabel kecerdasan intelektual, kecerdasan emosional, dan kecerdasan spiritual pada keputusan etis. Sedangkan moderated regression analysis digunakan untuk mengetahui pengaruh variabel moderasi locus of control dalam memoderasi pengaruh kecerdasan intelektual, kecerdasan emosional, dan kecerdasan spiritual pada keputusan etis.

\section{HASIL DAN PEMBAHASAN}

Populasi penelitian ini terdiri dari seluruh konsultan pajak yang bekerja pada kantor konsultan pajak di Daerah Bali, yakni sebanyak 156 orang konsultan pajak. Berdasarkan populasi penelitian ini, dilakukanlah pemilihan sampel dengan metode purposive sampling. Hasilnya, didapatkan sampel sejumlah 120 orang konsultan pajak. Kuesioner yang disebarkan sebanyak 120 kuesioner, dari jumlah kuesioner yang kembali hanya sejumlah 96 kuesioner, sehingga untuk analisa data digunakan sampel sebesar 96 kuesioner.

Tabel 2

Hasil AnalisisStatistikDeskriptif

\begin{tabular}{lcccc}
\hline \multicolumn{1}{c}{ Variabel } & Minimum & Maksimum & Mean & $\begin{array}{c}\text { Standar } \\
\text { Deviasi }\end{array}$ \\
\hline Kecerdasan intelektual & 28 & 45 & 35,083 & 4,680 \\
Kecerdasan emosional & 72 & 109 & 91,072 & 6,087 \\
Kecerdasan spiritual & 43 & 82 & 59,197 & 9,574 \\
Locus of control & 4 & 14 & 9,0104 & 1,933 \\
Keputusan etis & 11 & 18 & 13,427 & 2,060 \\
\hline
\end{tabular}

Sumber: Data diolah, 2017 
Berdasarkan Tabel 2 dapat diketahui nilai minimum, nilai maksimum, nilai mean, dan nilai standar deviasi setiap variabel. Standar deviasi menggambarkan rentangan antara nilai minimum dan maksimum suatu variabel. Nilai standar deviasi kecerdasan intelektual, kecerdasan emosional, kecerdasan spiritual masing-masing lebih kecil dari nilai mean. Hal ini menunjukkan variasi antara nilai maksimum dan nilai minimum variabel-variabel tersebut tergolong rendah.

Tabel 3

Hasil Uji Validitas dan Reliabilitas

\begin{tabular}{|c|c|c|c|c|}
\hline No & Variabel & Indikator & $\begin{array}{c}\text { Uji Validitas } \\
\text { Koefisien Korelasi }\end{array}$ & $\begin{array}{c}\text { Uji Reliabilitas } \\
\text { Cronbach's Alpha }\end{array}$ \\
\hline 1 & Kecerdasan Intelektual & $\begin{array}{c}\mathrm{X} 1.1 \\
\mathrm{X} 1.2 \\
\mathrm{X} 1.3 \\
\mathrm{X} 1.4 \\
\mathrm{X} 1.5 \\
\mathrm{X} 1.6 \\
\mathrm{X} 1.7 \\
\mathrm{X} 1.8 \\
\mathrm{X} 1.9 \\
\mathrm{X} 1.10\end{array}$ & $\begin{array}{l}0,720 \\
0,727 \\
0,757 \\
0,820 \\
0,808 \\
0,658 \\
0,801 \\
0,781 \\
0,769 \\
0,632\end{array}$ & 0,877 \\
\hline 2 & Kecerdasan Emosional & $\begin{array}{l}\mathrm{X} 2.1 \\
\mathrm{X} 2.2 \\
\mathrm{X} 2.3 \\
\mathrm{X} 2.4 \\
\mathrm{X} 2.5 \\
\mathrm{X} 2.6 \\
\mathrm{X} 2.7 \\
\mathrm{X} 2.8 \\
\mathrm{X} 2.9 \\
\mathrm{X} 2.10 \\
\mathrm{X} 2.11 \\
\mathrm{X} 2.12 \\
\mathrm{X} 2.13 \\
\mathrm{X} 2.14 \\
\mathrm{X} 2.15 \\
\mathrm{X} 2.16 \\
\mathrm{X} 2.17 \\
\mathrm{X} 2.18 \\
\mathrm{X} 2.19 \\
\mathrm{X} 2.20 \\
\mathrm{X} 2.21 \\
\mathrm{X} 2.22\end{array}$ & $\begin{array}{l}0,606 \\
0,641 \\
0,687 \\
0,667 \\
0,669 \\
0,669 \\
0,579 \\
0,581 \\
0,665 \\
0,641 \\
0,687 \\
0,667 \\
0,327 \\
0,493 \\
0,523 \\
0,374 \\
0,327 \\
0,665 \\
0,413 \\
0,423 \\
0,518 \\
0,522\end{array}$ & 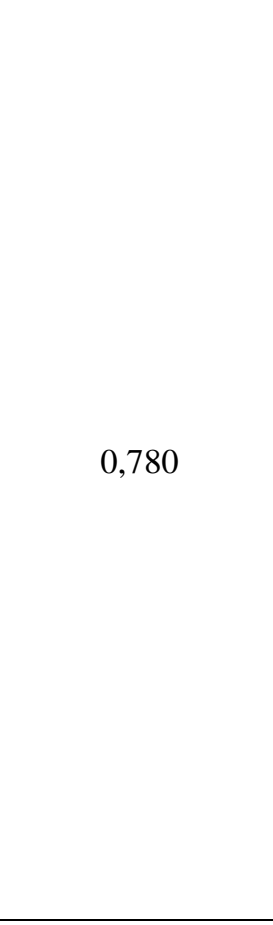 \\
\hline
\end{tabular}


I Made Indra Pratama, dan Dewa Gede Wirama. Pengaruh Kecerdasan Intelektual.....

\begin{tabular}{|c|c|c|c|c|}
\hline & & $\begin{array}{l}X 2.23 \\
\text { X2.24 }\end{array}$ & $\begin{array}{l}0,452 \\
0,361\end{array}$ & \\
\hline \multirow{18}{*}{3} & Kecerdasan Spiritual & $\mathrm{X} 3.1$ & 0,800 & \multirow{18}{*}{0,967} \\
\hline & & X3.2 & 0,790 & \\
\hline & & X3.3 & 0,798 & \\
\hline & & X3.4 & 0,895 & \\
\hline & & X3.5 & 0,732 & \\
\hline & & X3.6 & 0,782 & \\
\hline & & X3.7 & 0,764 & \\
\hline & & $\mathrm{X} 3.8$ & 0,830 & \\
\hline & & X3.9 & 0,712 & \\
\hline & & X3.10 & 0,736 & \\
\hline & & X3.11 & 0,764 & \\
\hline & & X3.12 & 0,842 & \\
\hline & & X3.13 & 0,830 & \\
\hline & & X3.14 & 0,837 & \\
\hline & & X3.15 & 0,851 & \\
\hline & & X3.16 & 0,784 & \\
\hline & & X3.17 & 0,804 & \\
\hline & & X3.18 & 0,895 & \\
\hline \multirow[t]{4}{*}{4} & Keputusan Etis & Y1.1 & 0,937 & \multirow{4}{*}{0,901} \\
\hline & & $\mathrm{Y} 1.2$ & 0,890 & \\
\hline & & Y1.3 & 0,810 & \\
\hline & & Y1.4 & 0,884 & \\
\hline
\end{tabular}

Sumber: data diolah, 2017

Berdasarkan Tabel 3 dapat dilihat hasil uji validitas kecerdasan intelektual $\left(\mathrm{X}_{1}\right)$, kecerdasan emosional $\left(\mathrm{X}_{2}\right)$, kecerdasan spiritual $\left(\mathrm{X}_{3}\right)$, dan keputusan etis $(\mathrm{Y})$ dapat diketahui bahwa masing-masing item pertanyaan mempunyai koefisien korelasi yang nilainya lebih besar dari 0,3 . Sehingga dapat dikatakan semua item pertanyaa valid atau lolos uji validitas.

Hasil uji reliabilitas menunjukkan bahwa nilai koefisien Cronbach's Alpha variabel kecerdasan intelektual $=0,877$, kecerdasan emosional $=0,780$ kecerdasan spiritual $=0,967$, dan keputusan etis $=0,901$. Semua nilai tersebut lebih besar dari 0,70 sehingga dapat disimpulkan bahwa semua butir pertanyaan terakit variabel penelitian ini reliabel. 
Tabel 4

Hasil Uji Normalitas

\begin{tabular}{ll}
\hline & Unstandardized Residual \\
\hline $\mathrm{N}$ & 96 \\
Kolmogorov-Smirnov Z & 1,108 \\
Asymp.Sig (2-tailed) & 0,172 \\
\hline
\end{tabular}

Berdasarkan Tabel 4 dapat dilihat bahwa Asymp. Sig (2-tailed) dalam One Sample Kolmogorov-Smirnov Test adalah 0,172. Nilai ini lebih besar dari signifikansi 0,05, sehingga data yang diuji terdistribusi normal.

Tabel 5

Hasil Uji Multikolinearitas

\begin{tabular}{cccc}
\hline No & Variabel & Nilai Tolerance & Nilai VIF \\
\hline 1 & Kecerdasan Intelektual & 0,950 & 1,053 \\
2 & Kecerdasan Emosional & 0,487 & 2,054 \\
3 & Kecerdasan Spiritual & 0,477 & 2,096 \\
\hline
\end{tabular}

Sumber: data diolah, 2017

Tabel 5 menunjukkan bahwa kedua variabel independen memiliki nilai tolerance $>$ 0,10 dan nilai Variance Inflation Factor (VIF) $<10$. Hal ini menandakan bahwa persamaan regresi ini tidak terdapat gejala multikolinearitas.

Tabel 6

\section{Hasil Uji Heteroskedastisitas}

\begin{tabular}{cccc}
\hline No & Variabel & $\mathrm{t}$ & Sig \\
\hline 1 & Kecerdasan Intelektual (X1) & 1,583 & 0,117 \\
2 & Kecerdasan Emosional (X2) & $-1,038$ & 0,302 \\
3 & Kecerdasan Spiritual (X3) & 1,950 & 0,054 \\
\hline
\end{tabular}

Sumber: data diolah, 2017

Berdasarkan Tabel 6 menunjukkan tidak ada satupun variabel independen yang berpengaruh signifikan terhadap variabel terikat Absolut Residual. Dapat dilihat dari nilai signifikannya sebesar 0,117 untuk variabel kecerdasan intelektual, sebesar 0,302 untuk variabel kecedasan emosional, dan untuk variabel 
I Made Indra Pratama, dan Dewa Gede Wirama. Pengaruh Kecerdasan Intelektual.....

kecerdasan spiritual sebesar 0,054. Semua nilai tersebut lebih besar dari alpha ( $\alpha$ $=0,05)$, sehingga dapat ditarik kesimpulan bahwa tidak terdapat heteroskedastisitas.

Tabel 7

Hasil Uji Regresi Linear Berganda

\begin{tabular}{|c|c|c|c|c|c|}
\hline \multirow[b]{2}{*}{ Model } & \multicolumn{2}{|c|}{$\begin{array}{c}\text { Unstandardized } \\
\text { Coefficients } \\
\end{array}$} & \multirow{2}{*}{$\begin{array}{c}\begin{array}{c}\text { Standardized } \\
\text { Coefficients }\end{array} \\
\text { Beta }\end{array}$} & \multirow{2}{*}{ t-hitung } & \multirow{2}{*}{ Sig. } \\
\hline & B & $\begin{array}{c}\text { Std. } \\
\text { Error }\end{array}$ & & & \\
\hline (Constant) & 3,903 & 1,630 & & 2,394 & 0,019 \\
\hline Kecerdasan Intelektual & 0,050 & 0,021 & 0,115 & 2,454 & 0,016 \\
\hline Kecerdasan Emosional & 0,050 & 0,022 & 0,148 & 2,276 & 0,025 \\
\hline Kecerdasan Spiritual & 0,208 & 0,014 & 0,968 & 14,693 & 0,000 \\
\hline Adjusted R-square & \multicolumn{5}{|l|}{0,803} \\
\hline Sig F & \multicolumn{5}{|l|}{0,000} \\
\hline
\end{tabular}

Berdasarkan Tabel 7, dapat diringkas model persamaan regresi pengaruh kecerdasan intelektual, kecerdasan emosional, dan kecerdasan spiritual pada keputusan etis konsultan pajak sebagai berikut:

$$
\mathrm{Y}=3,903+0,050 \mathrm{X}_{1}+0,050 \mathrm{X}_{2}+0,208 \mathrm{X}_{3}+\varepsilon
$$

Berdasarkan model persamaan regresi tersebut dapat dijelaskan informasi sebagai berikut.

1) Nilai konstanta sebesar 3,903 mengandung arti jika kecerdasan intelektual, kecerdasan emosional, dan kecerdasan spiritual dianggap konstan pada angka 0 (nol), maka nilai prediksi keputusan etis (Y) sebesar 3,903. Hal ini menunjukkan bahwa tanpa memiliki kecerdasan intelektual, kecerdasan emosional dan kecerdasan spiritual, konsultan pajak di Daerah Bali sudah dapat membuat keputusan etis. 
2) $\beta_{1}=0,050$, berarti apabila kecerdasan intelektual $\left(X_{1}\right)$ meningkat, maka akan mengakibatkan peningkatan pada keputusan etis (Y), dengan asumsi variabel $\mathrm{X}_{2}$ dan $\mathrm{X}_{3}$ yang dianggap konstan.

3) $\beta_{2}=0,050$, berarti apabila kecerdasan emosional $\left(X_{2}\right)$ meningkat, maka akan mengakibatkan peningkatan pada keputusan etis (Y), dengan asumsi variabel $\mathrm{X}_{1}$ dan $\mathrm{X}_{3}$ yang dianggap konstan.

4) $\beta_{3}=0,208$, berarti apabila kecerdasan spiritual $\left(X_{3}\right)$ meningkat, maka akan mengakibatkan peningkatan pada keputusan etis (Y), dengan asumsi variabel $\mathrm{X}_{1}$ dan $\mathrm{X}_{2}$ yang dianggap konstan.

\section{Tabel 8}

Hasil Uji Moderated Regression

\begin{tabular}{|c|c|c|c|c|c|}
\hline \multirow[b]{2}{*}{ Variabel } & \multicolumn{2}{|c|}{ Unstandardized coefficient } & \multirow{2}{*}{$\begin{array}{c}\text { Standardized } \\
\text { coefficient } \\
\text { Beta }\end{array}$} & \multirow{2}{*}{ t-hitung } & \multirow{2}{*}{ Sig. } \\
\hline & B & $\begin{array}{l}\text { Std. } \\
\text { Error }\end{array}$ & & & \\
\hline Constant & 3,751 & 1,593 & - & 2,354 & 0,021 \\
\hline $\begin{array}{l}\text { Kecerdasan } \\
\text { Intelektual } \\
\left(\mathrm{X}_{1)}\right.\end{array}$ & $-0,156$ & 0,068 & $-0,354$ & $-2,305$ & 0,024 \\
\hline $\begin{array}{l}\text { Kecerdasan } \\
\text { Emosional } \\
\left(\mathrm{X}_{2}\right)\end{array}$ & $-0,49$ & 0,022 & $-0,145$ & $-2,284$ & 0,025 \\
\hline $\begin{array}{l}\text { Kecerdasan } \\
\text { Spiritual }\left(\mathrm{X}_{3}\right)\end{array}$ & 0,303 & 0,041 & 1,406 & 7,353 & 0,000 \\
\hline $\begin{array}{l}\mathrm{X}_{1} \times \text { Locus of } \\
\text { Control }\end{array}$ & 0,012 & 0,004 & 0,782 & 2,802 & 0,006 \\
\hline $\begin{array}{l}\mathrm{X}_{2} \times \text { Locus of } \\
\text { Control }\end{array}$ & 0,014 & 0,007 & 0,105 & 2,120 & 0,037 \\
\hline $\begin{array}{l}\mathrm{X}_{3} \times \text { Locus of } \\
\text { Control }\end{array}$ & 0,006 & 0,002 & 0,678 & 2,584 & 0,011 \\
\hline $\mathrm{R}$ & & 0,917 & & & \\
\hline Adjusted $\mathrm{R}^{2}$ & & 0,830 & & & \\
\hline $\mathrm{F}_{\text {hitung }}$ & & 78,424 & & & \\
\hline Sig F & & 0,000 & & & \\
\hline
\end{tabular}


I Made Indra Pratama, dan Dewa Gede Wirama. Pengaruh Kecerdasan Intelektual.....

Berdasarkan Tabel 8, dapat diringkas model persamaan regresi moderasi pengaruh interaksi locus of control pada kecerdasan intelektual, kecerdasan emosional, dan kecerdasan spiritual pada keputusan etis konsultan pajak sebagai berikut:

$Y=3,751-0,156 X_{1}-0,049 X_{2}+0,303 X_{3}+0,012 X_{1} X_{4}+0,014 X_{2} X_{4}+0,006 X_{3} X_{4}$ $+\mathrm{e}$

Berdasarkan model persamaan regresi tersebut dapat dijelaskan informasi sebagai berikut.

1) Nilai koefisien interaksi variabel kecerdasan intelektual dan locus of control adalah $\beta_{5}=0,012$ dengan tingkat signifikansi sebesar 0,006 , artinya jika terjadi peningkatan pada interaksi variabel kecerdasan intelektual dan locus of control, maka variabel keputusan etis cenderung akan mengalami peningkatan dengan asumsi bahwa variabel bebas lainnya adalah konstan atau tidak mengalami perubahan.

2) Nilai koefisien interaksi variabel kecerdasan emosional dan locus of control adalah $\beta_{6}=0,014$ dengan tingkat signifikansi sebesar 0,037 , artinya jika terjadi peningkatan pada interaksi variabel kecerdasan emosional dan locus of control, maka variabel keputusan etis cenderung akan mengalami peningkatan dengan asumsi bahwa variabel bebas lainnya adalah konstan atau tidak mengalami perubahan.

3) Nilai koefisien interaksi variabel kecerdasan spiritual dan locus of control adalah $\beta_{7}=0,006$ dengan tingkat signifikansi sebesar 0,011, artinya jika terjadi peningkatan pada interaksi variabel kecerdasan spiritual dan locus of control, 
maka variabel keputusan etis cenderung akan mengalami peningkatan dengan asumsi bahwa variabel bebas lainnya adalah konstan atau tidak mengalami perubahan.

Berdasarkan hasil uji F pada Tabel 8, dihasilkan tingkat signifikansi 0,000 lebih kecil dari $\alpha=0,05$. Dengan demikian model penelitian ini layak digunakan untuk melakukan pembuktian atas hipotesis yang dibentuk atau dengan kata lain model fit.

Dari hasil uji koefisien determinasi pada Tabel 8, variabel moderasi yang dalam penelitian ini yaitu interaksi antara kecerdasan intelektual dan locus of control memiliki tingkat signifikansi sebesar 0,006, interaksi antara kecerdasan emosional dan locus of control memiliki tingkat signifikansi sebesar 0,037, dan interaksi antara kecerdasan spiritual dan locus of control memiliki tingkat signifikansi sebesar 0,011. Sehingga dapat disimpulkan bahwa variabel locus of control merupakan variabel moderasi untuk hubungan antara kecerdasan intelektual, kecerdasan emosional, dan kecerdasan spiritual dengan keputusan etis. Berdasarkan hasil analisis regresi linier berganda pada Tabel 7, hasilnya menunjukkan bahwa kecerdasan intelektual berpengaruh dengan arah positif dan signifikan pada keputusan etis konsultan pajak di Daerah Bali. Hal ini ditunjukkan dengan nilai signifikansi sebesar 0,016 yang nilainya lebih kecil dari tingkat signifikan yang ditetapkan $(\alpha=0,05)$ dan memiliki nilai koefisien sebesar 0,050. Sehingga hipotesis pertama $\left(\mathrm{H}_{1}\right)$ diterima yakni kecerdasan intelektual berpengaruh pada keputusan etis konsultan pajak di Daerah Bali. 
I Made Indra Pratama, dan Dewa Gede Wirama. Pengaruh Kecerdasan Intelektual.....

Untuk variabel kecerdasan emosional hasilnya menunjukkan bahwa kecerdasan emosional berpengaruh dengan arah positif dan signifikan pada keputusan etis konsultan pajak di Daerah Bali. Hal ini ditunjukkan dengan nilai signifikansi sebesar 0,025 yang nilainya lebih kecil dari tingkat signifikan yang ditetapkan $(\alpha=0,05)$ dan memiliki nilai koefisien sebesar 0,050 . Sehingga hipotesis kedua $\left(\mathrm{H}_{2}\right)$ diterima yakni kecerdasan emosional berpengaruh pada keputusan etis konsultan pajak di Daerah Bali.

Untuk variabel kecerdasan spiritual hasilnya menunjukkan bahwa kecerdasan spiritual berpengaruh dengan arah positif dan signifikan pada keputusan etis konsultan pajak di Daerah Bali. Hal ini ditunjukkan dengan nilai signifikansi sebesar 0,000 yang nilainya lebih kecil dari tingkat signifikan yang ditetapkan $(\alpha=0,05)$ dan memiliki nilai koefisien sebesar 0,208 . Sehingga hipotesis ketiga $\left(\mathrm{H}_{3}\right)$ diterima yakni kecerdasan spiritual berpengaruh pada keputusan etis konsultan pajak di Daerah Bali.

Berdasarkan hasil analisis regresi moderasi pada Tabel 8, hasilnya menunjukkan bahwa pengaruh kecerdasan intelektual pada keputusan etis meningkat setelah diinteraksian dengan locus of control. Hal ini didukung dengan hasil analisis yang menggambarkan bahwa nilai signifikansi sebesar 0,006 yang nilainya lebih kecil dari tingkat signifikan yang ditetapkan $(\alpha=0,05)$ dan memiliki koefisien beta sebesar 0,012, hubungan moderasi positif ini dapat dijelaskan bahwa keputusan etis seorang konsultan pajak sebagai pengaruh dari kecerdasan intelektual akan lebih tinggi atau lebih etis jika konsultan pajak memiliki locus of control internal. Hasil ini menerima hipotesis keempat $\left(\mathrm{H}_{4}\right)$ 
yang menunjukkan bahwa locus of control dapat memoderasi pengaruh kecerdasan intelektual pada keputusan etis konsultan pajak di Daerah Bali.

Interaksi variabel locus of control dengan variabel kecerdasan emosional hasilnya menunjukkan bahwa pengaruh kecerdasan emosional pada keputusan etis meningkat setelah diinteraksikan dengan locus of control. Hal ini didukung dengan hasil analisis yang menggambarkan bahwa nilai signifikansi sebesar 0,037 yang nilainya lebih kecil dari tingkat signifikan yang ditetapkan $(\alpha=0,05)$ dan memiliki koefisien beta sebesar 0,014, hubungan moderasi positif ini dapat dijelaskan bahwa keputusan etis seorang konsultan pajak sebagai pengaruh dari kecerdasan emosional akan lebih tinggi atau lebih etis jika konsultan pajak memiliki locus of control internal. Hasil ini menerima hipotesis kelima $\left(\mathrm{H}_{5}\right)$ yang menunjukkan bahwa locus of control dapat memoderasi pengaruh kecerdasan emosional pada keputusan etis konsultan pajak di Daerah Bali.

Interaksi variabel locus of control pada variabel kecerdasan spiritual, hasilnya menunjukkan bahwa pengaruh kecerdasan spiritual pada keputusan etis meningkat setelah diinteraksikan dengan locus of control. Hal ini didukung dengan hasil analisis yang menggambarkan bahwa nilai signifikansi sebesar 0,011 yang nilainya lebih kecil dari tingkat signifikan yang ditetapkan $(\alpha=0,05)$ dan memiliki koefisien beta sebesar 0,006, hubungan moderasi positif ini dapat dijelaskan bahwa keputusan etis seorang konsultan pajak sebagai pengaruh dari kecerdasan spiritual akan lebih tinggi atau lebih etis jika konsultan pajak memiliki locus of control internal. Hasil ini menerima hipotesis kelima $\left(\mathrm{H}_{6}\right)$ yang 
I Made Indra Pratama, dan Dewa Gede Wirama. Pengaruh Kecerdasan Intelektual.....

menunjukkan bahwa locus of control dapat memoderasi pengaruh kecerdasan spiritual pada keputusan etis konsultan pajak di Daerah Bali.

\section{SIMPULANDANSARAN}

Berdasarkan hasil analisis data dan pembahasan, dapat disimpulkan sebagai berikut: 1) kecerdasan intelektual berpengaruh positif pada keputusan etis konsultan pajak di Daerah Bali. Hasil ini berarti bahwa semakin tinggi kecerdasan intelektual yang dimiliki oleh seorang konsultan pajak di Daerah Bali maka keputusan yang dibuatnya akan semakin etis; 2) kecerdasan emosional berpengaruh positif pada keputusan etis konsultan pajak di Daerah Bali. Hasil ini berarti bahwa semakin tinggi kecerdasan emosional yang dimiliki oleh seorang konsultan pajak di Daerah Bali maka keputusan yang dibuatnya akan semakin etis; 3) kecerdasan spiritual berpengaruh positif pada keputusan etis konsultan pajak di Daerah Bali. Hasil ini berarti bahwa semakin tinggi kecerdasan spiritual yang dimiliki oleh seorang konsultan pajak di Daerah Bali maka keputusan yang dibuatnya akan semakin etis; 4) locus of control memoderasi pengaruh kecerdasan intelektual pada keputusan etis konsultan pajak di Daerah Bali.Hasil pengujian moderasi tersebut mengindikasikan hubungan moderasi positif, ini dapat dijelaskan bahwakeputusan etis konsultan pajak di Daerah Bali sebagai pengaruh kecerdasan intelektual akan lebih tinggi atau lebih etis jika konsultan pajak di Daerah Bali memiliki locus of control internal; 5)locus of control memoderasi pengaruh kecerdasan emosional pada keputusan etis konsultan pajak di Daerah Bali. Hasil pengujian moderasi tersebut mengindikasikan hubungan moderasi 
positif, ini dapat dijelaskan bahwa keputusan etis konsultan pajak di Daerah Bali sebagai pengaruh kecerdasan emosional akan lebih tinggi atau lebih etis jika konsultan pajak di Daerah Bali memiliki locus of control internal; 6)locus of control memoderasi pengaruh kecerdasan spiritual pada keputusan etis konsultan pajak di Daerah Bali. Hasil pengujian moderasi tersebut mengindikasikan hubungan moderasi positif, ini dapat dijelaskan bahwa keputusan etis konsultan pajak di Daerah Bali sebagai pengaruh kecerdasan spiritual akan lebih tinggi atau lebih etis jika konsultan pajak di Daerah Bali memiliki locus of control internal.

Penelitian ini memiliki keterbatasan pada kesimpulan yang didasarkan pada persepsi dari konsultan pajak yang berada di Daerah Bali saja. Penelitian selanjutnya diharapkan dapat memperluas populasi penelitian yang tidak terbatas hanya pada konsultan pajak di Daerah Bali saja.

Selain itu penelitian ini menggunakan kuesioner yang bersifat self assessment (responden menilai dirinya sendiri), jadi dikhawatirkan responden hanya akan mengarahkan responnya ke arah yang positif. Penelitian selanjutnya dapat dikembangkan melalui studi laboratorium (eksperimen) untuk memberikan hasil penelitian yang lebih meyakinkan.

Nilai $\mathrm{R}^{2}$ sebesar 0,830 , ini menunjukkan bahwa sebesar $83 \%$ keputusan etis dipengaruhi oleh variabel kecerdasan intelektual, kecerdasan emosional, kecerdasan spiritual dan variabel locus of control, sedangkan $17 \%$ dipengaruhi oleh variabel-variabel lain yang tidak disajikan dalam model penelitian ini. Hal ini menjadi peluang bagi peneliti selanjutnya untuk mengembangkan penelitian terkait faktor-faktor yang mempengaruhi keputusan etis. 


\section{REFERENSI}

Abdurrahman dan Yuliani. 2011. Determinasi Pengambilan Keputusan Etis Auditor Internal (Studi Empiris pada BUMN dai Magelang dan Temanggung). Widya Warta. No. 02 Tahun XXXV/Juli. Surabaya.

Achmad, T. 2014. Menjadikan Konsultan Pajak sebagai Agents of Tax Compliance. Available from: http://www. pajak.go.id/ content/article/ menjadikan-konsultan-pajak-sebagai-agents-taxcompliance. Diakses pada tanggal 16 Juli 2016

Agustini, dan Herawati Nyoman. 2013. Pengaruh Kecerdasan Intelektual, Kecerdasan Emosional dan Kecerdasan Spiritual Terhadap Sikap Etis Mahasiswa Akuntansi Universitas Pendidikan Ganesha Singaraja. Jurnal Ilmiah Mahasiswa Akuntansi S1, Vol 1: 1.

Amellia, Melli. 2012. "Pengaruh Kecerdasan Emosional Auditor Eksternal Dan Kecerdasan Intelektual Auditor Eksekutif Terhadap Auditor Eksternal Dengan Kepercayaan Diri Sebagai Variabel Moderating" (skripsi). Jakarta: Universitas Islam Negeri Syarif Hidayatullah Jakarta.

Ashari, 2013. Corruption Awareness, Ethical Sensitivity, Professional Skepticism And Risk Of Corruption Assessment: Exploring The Multiple Relationship In Indonesian Case. Available from: https://papers.ssrn.com/sol3/papers.cfm? abstract_id $=2196249 \&$ rec $=1 \&$ srcabs $=965453 \&$ alg $=7 \&$ pos $=9$. Diakses pada tanggal 13 Juli 2016.

Atmaja Anantawikrama Tungga, dan Saputra Komang Adi Kurniawan, 2014. The Effect of Emotional Spiritual Quotient (ESQ) To Ethical Behavior In Accounting Profession With Tri Hita Karana Culture's As A Moderating Variable. Research Journal of Finance and Accounting, Vol $5: 7$.

Budileksmana, A. 2000. Manfaat dan Peranan Konsultan Pajak dalam Era Self Assesment Perpajakan. Jurnal Akuntansi dan Investasi, Vol 1: 77-84.

Devos, K. 2012. The Impact of Tax Professionals Upon the Compliance Behavior of Australian Individual Taxpayers. Revenue Law Journal, Vol 22 (1) : 26.

Fallah, Syaikhul. 2006. "Pengaruh Budaya Etis Organisasi Dan Orientasi Etika Terhadap Sensitivitas Etika (Studi Empiris Tentang Pemeriksa Internal di Bawasda Pemda Papua)" (tesis). Semarang: Universitas Diponegoro.

Goleman, D. 2005. Kecerdasan Emosi : Mengapa Emotional Intelligence Lebih Tinggi Daripada IQ, Alih Bahasa : T. Hermay. Jakarta: PT. Gramedia Pustaka Utama. 
Gusti, Maghrifah dan Syahril, Ali. 2007. Hubungan Skeptisisme dan Situasi audit, Etika, Pengalaman serta Keahlian Audit dengan Ketepatan Pemberian Opini Auditor oleh Akuntan Publik. Jurnal Simposium Nasional Akuntansi Ke XI. Pontianak

Hughes, F. J. dan P. Moizer. 2015. Assessing the quality of services provided by UK tax practitioners. eJournal of Tax Research, Vol 13 (1) : 51-75.

Idrus, Muhammad. 2002. Kecerdasan Spiritual Mahasiswa Yogyakarta, Psikologi Phronesis. Jurnal Ilmiah dan Terapan, Vol 4 : 8.

Januarti, Indira. 2011. Analisis pengaruh pengalaman auditor, komitmen profesional, orientasi etis, dan nilai etika terhadap persepsi dan pertimbangan etis (auditor badan pemeriksa keuangan Indonesia). Simposium Nasional Akuntansi $X I V$. Aceh.

Jones, G. E. dan Kavanagh, M. J. 1996. An Experimental Examination of The Effects of Individual and Situational Factors on Unethical Behavioral Intentions in The Workplace. Journal of Business Ethics, Vol: 15(5) : 511-523.

Lisda, Afria. 2009. "Pengaruh Kemampuan Intelektual, Kecerdasan Emosional dan Kecerdasan Spiritual Terhadap Perilaku Etis Auditor Serta Dampaknya Pada Kinerja". "skripsi". Jakarta: Universitas Islam Negeri Syarif.

Mahadewi. 2015. Pengaruh Intelligence Quotient (iq), dan Emotional Spiritual Quotients (esq) Terhadap Perilaku Etis Profesi Akuntan Publik dengan Locus of Control Sebagai Variabel Moderasi (studi empiris pada kantor akuntan publik di wilayah bali). E-journal Akuntansi, Vol: $3: 1$.

Rotter, J.B. 1966. Generalized expectancies for internal versus external control of reinforcement. Psychological Monographs, Vol. 80 : 1-28.

Shaub. 1993. The Effects of Auditor's Ethical Orientation on Commitment and Ethical Sensitivity. Behavioral Research in Accounting, Vol. 5 : 145-169.

Suadnyana Pasek. 2015. "Pengaruh Kecerdasan Intelektual Pada Pemahaman Akuntansi Dengan Kecerdasan Emosi dan Kecerdasan Spiritual Sebagai Variabel Pemoderasi”(tesis). Denpasar: Universitas Udayana.

Suardika Agus. 2015. "Pengaruh Idealisme, Komitmen Profesional dan Skeptisme Profesional Pada Pembuatan Keputusan Etis Konsultan Pajak di Provinsi Bali” (tesis). Denpasar: Universitas Udayana.

Tan, L. M. 1999. Taxpayers' Preference for Type of Advice from Tax Practitioner: A Preliminary Examination. Journal of Economic Psychology, Vol: 20 (4) : 431447. 
I Made Indra Pratama, dan Dewa Gede Wirama. Pengaruh Kecerdasan Intelektual.....

Tarjo dan I. Kusumawati. 2006. Analisis Perilaku Wajib Pajak Orang Pribadi terhadap Pelaksanaan Self Assessment System: Suatu Studi di Bangkalan. Jurnal Akuntansi dan Auditing Indonesia, Vol: 10 (1) : 101 - 120.

Tikollah. 2006. Pengaruh Kecerdasan Intelektual, Emosional, dan Kecerdasan Spiritual Terhadap Sikap Etis Mahasiswa Akuntansi (Studi Pada Perguruan Tinggi Negeri di Kota Makassar Provinsi Sulawesi Selatan). Simposium Nasional Akuntansi IX Padang.

Trevino, Linda Klebe. 1986. Ethical Decision Making in Organization: A Person

Uyar, M. dan Ozer, G. 2011. The Ethical Orientation And Professional Commitment: An Empirical Examination On Turkish Accountants. Availablefrom:

https://www.academia.edu/4245921/The_ethical_orientation_and_professional_co mmitment_An_empirical_examination_on_Turkish_Accountants. Diakses pada tanggal 14 Juli 2016.

Zohar, Danah dan Marshall.2007. SQ: Memanfaatkan Kecerdasan Spiritual Dalam Berpikir Integralistik dan Holistik Untuk Memaknai Kehidupan” Cetakan II. Diterjemahkan oleh Rahmi Astuti, Ahmad Najib Burhani dan Ahmad Baiquni. Bandung: Mizan.

Greenhaus, J.H., dan Callanan, G. A. 2006. Encylopedia of career development. Vol. 2. United State of America: Sage Publications, Inc.

Http://www.pajak.go.id/content/article/penerimaan-pajak-tahun-2016.Diakses pada tanggal 16 Juli 2016 